\title{
MOBILE LEARNING IN MALAYSIA EDUCATION INSTITUTIONS
}

\author{
Maslin Masrom, Universiti Teknologi Malaysia, maslin.kl@utm.my \\ Amirah Syahmi Nadzari, Universiti Teknologi Malaysia, amirah.syahmi19@gmail.com \\ Nik Hasnaa Nik Mahmood, Universiti Teknologi Malaysia,nikhasnaa.kl@utm.my \\ Wan NormezaWan Zakaria, Universiti Teknologi Malaysia,normeza.kl@utm.my \\ Nor Raihana Mohd Ali, Universiti Teknologi Malaysia, raihana.kl@utm.my
}

\begin{abstract}
The present of internet and widespread usage of computers has created a new term for distance learning which is known as the mobile learning. Mobile learning is one of the major evolving areas in recent years of educational field. Mobile learning or 'm-learning' assists learning process through mobile devices such as tablet computers and smartphones. The present technologies have made ease of access to all materials and resources. Albeit the ubiquitousness of mobile learning that had gained many interest educational institutions, the usage is still considered in early stage in most countries including Malaysia. Therefore, the objective of this study is to explore the current use of mobile learning in Malaysia's education institutions. The study was done through qualitative approach by analyzing the past studies on m-learning. The findings indicated that the use and positive impact of ' $m$ learning' application to deliver courses in education institutions are required in Malaysia.
\end{abstract}

Keywords: Mobile Learning, Mobile Application, Education Institution, Malaysia

\section{INTRODUCTION}

Youth and mobile devices are inseparable nowadays. Due to growth of technology in mobile devices and increasing demand of the mobile devices, the prices are decreasing (Moura and Carvarlho, 2008). The growth of technology in communication devices and tools has led many industries and sectors to be inter-connected with mobile applications in sense that both influence and are influenced by these mobile applications.

A press release by The World Bank in 2012 entitled 'Maximizing Mobile' stated that about three quarter of the world population including much of the developing world, now has accessed to a mobile phone (Russell and Ciesliek, 2012). The number of mobile subscriptions in use worldwide, both pre-paid and post-paid, has grown from fewer than 1 billion in 2000 to over 6 billion now, of which nearly 5 billion in developing countries. A mobile report by Ericsson Mobile in 2014 reveals that the on-going growth of the smartphone market is not likely to slow down any time soon. This is due to increasing numbers of users coming online. According to the study, which looks at data forecasts up to the turn of the next decade, $90 \%$ of the world's population over the age of six will have a mobile phone. By 2020, Ericsson predicts there will be at least 6.1 billion smartphone subscriptions globally.

The development of improved tools and technology has also increased the demand for mobile devices for educational purposes (Little, 2013). Hussin, Manap, Amir, and Krish (2012) have stated that mobile learning has great potential to be an effective learning tool due to the rapid growth of new generation of mobile devices for example tablets, mobile phones, and also the advancement in wireless technology. Some researchers suggested that learning activities must be supported by additional activities out of the classroom (Ozdamli and Cavus, 2011). Nevertheless, 'm-learning' is still in the early stage in most countries. Traxler (2007) believed on the perception of mobile education is still a new issue and people still cannot get the picture of mobile learning. 


\section{What is Mobile Learning?}

Mobile learning is obviously not merely a combination of 'mobile' and 'learning'. There is no proper or standard definition of mobile learning as many authors and researchers have derived with various definitions.

Different communities give different meanings of ' $m$-learning' (Mehdipour and Zerehkafi, 2013). Mobile learning is referred as any sort of learning that happens when learner is not a fixed, predetermined location and learning that happens when learner takes advantage of learning opportunities offered by mobile technology ( $O$ ' Malley, Vavoula, Sharples, Lefrere, and Glew, 2005). Low and O'Connel (2006) stated that 'm-learning' increase the flexibility of learning and gives freedom feelings to student. It is also believe that ' $\mathrm{m}$-learning' helps to increase the performances of learners by making learning accessible. It is when learners can stay connected with their learning environments while going mobile (Yi, Liao, Huang, and Hwang, 2009).

Mobile learning also eliminates geographic boundaries at the same time provides collaborating learning environment between foreign groups. The advances in mobile devices have facilitated the use of multimedia in mobile application and allow learners to have access to variety of learning resources (Huang, Chen, and Chun, 2009). Crescentee and Lee (2011) and Lan and Sie (2011) stated that with the use of mobile devices and availability of internet, learners are able to obtain learning material anytime and anywhere.

However, to simplify the definition, mobile learning or ' $\mathrm{m}$-learning' is defined as the subset of 'e-learning' while 'elearning' is the subset of distance learning. It is a type of distance education that focuses on learning across context and learning with mobile devices. In other words, 'm-learning' is the ability to use mobile devices to support teaching and learning.

\section{Mobile Learning in Malaysia}

The study on mobile apps learning in Malaysia began in 2010. Wahab, Osman, and Ismail (2010) had conducted a study on Engaging Children to Science Subject: A Heuristic Evaluation of Mobile Learning Prototype. The mlearning prototype was designed for the primary school students with the age range of 10 to 12 years old. The language used for the mobile application was English. It contains notes and exercise of chapter 'The Basic Needs of Human' and the contents were extracted from the textbook and workbook. The software used to develop the prototype were JCreator LE and Sun Wireless Toolkit 2.5.2.

Wendeson, Ahmad, and Haron, (2010) developed Mobile Learning Tool for Windows mobile platform in order to add values on the existing conventional and electronic learning. The tool included five modules which are lecture materials, assignment, academic information, discussion and quizzes for the structural programming course.

Then, Kamaludin, Kasim, Selamat, and Hui (2012) developed an m-learning application for Basic Computer Architecture course. The application was built to assist teaching and learning method because the use of mobile devices shown that students were interested in study as well as help them to improve their study achievement. Besides, the content for this mobile application is aiming on some modules which are notes, flash card and quiz that can be used even the students are offline from mobile devices.

The recent mobile learning apps is developed by Nawi, Hamzah and Sattai (2014). According to Nawi et al. (2014), the objective of the research is to build a mobile application for Islamic Education Course. Afterwards, the application is evaluated by teachers and students. The result from the research shown that teachers and students are very satisfied with the mobile application built for Islamic Education Course. Therefore, there is a positive potential among the teachers and students to use the mobile learning. Moreover, mobile application was correctly build to satisfy teachers and students need. Table 1 lists some of the mobile learning apps that have been developed in Malaysia. 
Table 1. Mobile Learning Apps in Malaysia

\begin{tabular}{|c|l|l|l|}
\hline No. & \multicolumn{1}{|c|}{ Authors } & \multicolumn{1}{|c|}{ Course/Apps } & Educational Level \\
\hline 1 & Wahab, N. A., Osman, A. and Ismail, M. H. (2010) & Science & Primary Education \\
\hline 2 & Wendeson, S., Ahmad, W. F. W, and Haron, N. S. (2010) & $\begin{array}{l}\text { Structural } \\
\text { Programming }\end{array}$ & Higher Education \\
\hline 3 & $\begin{array}{l}\text { Kamaludin, H., Kasim, S., Selamat, N., and Hui, B. C. } \\
(2012)\end{array}$ & $\begin{array}{l}\text { Basic Computer } \\
\text { Architecture }\end{array}$ & Higher Education \\
\hline 4 & Nawi A., Hamzah, M. I, and Sattai, S. A. A. (2014) & Islamic Education & $\begin{array}{l}\text { Secondary } \\
\text { Education }\end{array}$ \\
\hline
\end{tabular}

\section{RESEARCH METHODOLOGY}

The study employed qualitative approach whereby data from secondary sources, that is, previous researches gathered and analyzed. Besides analyzing previous research done on mobile learning, the other secondary sources for this study derive from a press release The World Bank in 2012 and Ericsson Mobile's Mobility Report (2014). The Hand Phone Users Surveys 2014 issued by the Malaysian Communications and Multimedia Commission are also used as secondary source to justify the used of smartphones for mobile learning in Malaysia.

\section{FINDINGS AND DISCUSSIONS}

The analysis indicates that there is the need of mobile learning in education sector. Kamaludin et al. (2012) stated that since mobile learning is truly independent in terms of time and place, it is suitable for learning practice in line with the increase use of the mobile devices and the advancement of learning opportunities and learning resources. Furthermore, the increasing range of access devices will capable 'm-learning' to function with the enhancement of learning resources and management system.

Regard to the readiness of Malaysia's citizen about the implementation of 'm-learning' apps in Malaysia Higher Education, the statistics by Malaysian Communications and Multimedia Commission in 2014 shown that the number of mobile phones used by the citizen exceeds the number of the citizen. The number of mobile phones used by the citizen is $30,379,000$ while the population is $28,250,000$. This statistics clearly reveals that most of Malaysian own a mobile phone and able to operate it themselves. As in overall user base, smartphone demographics count more males (55.9\%) than females (44.1\%). Statistically, 1 in 2 Malaysians are smartphone users now. This statistics is supported by TNS Malaysia Connected Consumer Study (2014) sponsored by Google. In the research, it was also found that smartphone is the most commonly used connected device in Malaysia.

Further, the surveys also explored the importance of mobile phone in the daily life of Malaysians. Mobile phones are claimed as essential in $44.8 \%$ of consumers' everyday lives. At a much more noteworthy rate, $51.5 \%$ of consumers say that mobile phones are very important. Just an unimportant 3.7\% said that their mobile phones are not critical in their day by day life. Basically, users' behaviour indicates that they have strong connection to their mobile phones particularly to the younger users. In terms of age band, the surveys showed that adults account for $73.1 \%$ of all mobile phone users. Users are considered as adults if they aged from 20 to 40 years old at last birthday. Grouped into educational background, $37.5 \%$ of users have high education attainment. To certify the statement that most university students own a smartphone, a survey was done by Song, Murphy, and Farley in 2013 to compare the ownership of smartphones in the years 2008 and 2013. The surveys show that about $80 \%$ of the students owning a smartphone compared to the year 2008 where none of them owning a smartphone. In a nutshell, by relating the robust connection between users and mobile phone, age band of most users and their educational background, this is a good indication for using mobile learning in university. 
The readiness of lecturers on mobile learning among lecturers, a related survey done by Hamat, Embi and Abu Hassan in 2012 showed that $65 \%$ of the respondents (lecturers) are owners of smart or mobile phones. Besides that, the respondents expressed a supportive perception of m-learning although majority of them have never used it (79\%). Majority of the respondents (85.7\%) likewise believe that mobile learning would be advantageous for their students. The main reason is the flexibility of the mobile learning.

Correspondingly, to discuss the student acceptance and readiness on mobile technology usage for learning, studies were done by Suki and Suki (2010) and Mahat, Ayub and Su (2012). Study done by Mahat et. al (2012) also examined the relationships between students self-efficacy and readiness towards m-learning with the students perception on the effectiveness of m-learning. The results indicated that students had a high level of personal innovativeness and mobile readiness. The result in study by Suki et. al (2010) showed that learners have yet to acknowledge that the concept of mobility in learning is relevant to the learning process, apart from using smartphones for casual utilization. Nonetheless, this is not a restriction as the students are willing to increase their learning exposure using mobile device by exploring this new learning technology and environment.

Lastly, it is believes that there are factors that inhibit the acceptance of m-learning in Malaysia. Six factors identified in a research done by Chong, Chong and Ooi are perceived ease of use, perceived usefulness, technical feasibility, cost effectiveness, quality of services and cultural aspects. The outcomes of the research demonstrate that perceived ease of use, perceived usefulness, quality of services and cultural aspects have remarkable and positive effects in the acceptance of m-learning in Malaysia.

\section{SUMMARY}

According to the findings, there is significant growth in number of study in the area of mobile learning in Malaysia from 2010 till today. Despite the fact that there are numbers of mobile learning initiatives in higher education, the acceptance of mobile learning in education is still not broad in Malaysia. However, even though the mobile learning is still unfamiliar within the culture, the ownership of smartphones is increasing among the students. In spite the infancy of mobile learning in Malaysia, the lecturers and students shows their willingness to adopt the mobility in learning. To sum up, further research and improvement needs to be explored so that the adoption and utilization of mobile learning in higher education would be profitable for teachers, lecturers, students, schools, and universities. The mobile learning is gaining popularity in the education sectors. Undoubtedly, the application of mobile learning in higher education has a positive impact in Malaysia.

\section{ACKNOWLEDGEMENT}

The authors would like to thank Universiti Teknologi Malaysia for the Instructional Development Grant (IDG) (UTM -Vote No: 4J146).

\section{REFERENCES}

Chong, J.-L., Chong, A. Y.-L., Ooi, K.-B., \& Lin, B. (2011). An empirical analysis of the adoption of m-learning in Malaysia. International Journal of Mobile Communications, 9(1), 1-18.

Communications \& Multimedia Pocket Book of Statistics, Malaysian Communications and Multimedia Commision, 2014.

Crescente, M.L \& Lee, D. (2011). Critical issues of M-Learning: design models, adoption processes, and future trends. Journal of the Chinese Institute of Industrial Engineers, 28(2), 111-123. 
Ericsson Mobile. (November 2014). Mobility Report on the Pulse of the Networked Society. Retrieved from http://www.ericsson.com/res/docs/2014/ericsson-mobility-report-november-2014.pdf.

Hamat, A., Embi, M. A., \& Abu Hassan, H. (2012). Mobile learning readiness among UKM lecturers. Universiti Kebangsaan Malaysia Teaching and Learning Congress 2011, I(59), 406-410.

Huang, C. J., Chen, H. X., \& Chen, C. H. Developing argumentation processing agents for computer-supported collaborative learning. Expert Systems with Applications, 36, 2615-2624.

Hussin, S., Manap, M. R., Amir, Z. \& Krish, P. (2012). Mobile learning readiness among Malaysian students at higher learning institutes. Asian Social Science, 8(12), 276-283.

Kamaludin, H., Kasim, S., Selamat, N., \& Hui, B. C. (2012). M-Learning application for Basic Computer Architecture. 2012 International Conference on Innovation, Management and Technology Research (ICIMTR2012), Malacca, Malaysia, 546-549.

Lan, Y. F., \& Sie, Y. S. (2010). Using RSS to support mobile learning based on media richness theory. Computers \& Education, 55(2), 723-732.

Little, B. (2013). Issues in mobile learning technology. Human Resource Management International Digest, 21(3), 26-29.

Low, L. \& O'Connell, M. (2006). Learner-centric design of digital mobile learning. Paper presented at Learning on the Move. Retrieved from http://www.academia.edu/941536/Learner-

centric_design_of_digital_mobile_learning.

Mahat, J., Ayub, A. F. M., \& Su Luan, W. (2012). An assessment of atudents' mobile self-efficacy, readiness and personal innovativeness towards mobile learning in higher education in Malaysia. 12th International Educational Technology Conference - Ietc 2012, 64, 284-290.

Mehdipour, Y. and Zerehkafi (2013). Mobile learning for education: benefits and challenges, International Journal of Computational Engineering Research, 3(6), 93-101.

Moura, A. \& Carvalho, A. A. (2008). Mobile learning: teaching and learning with mobile phones and Podcasts. Eighth IEEE International Conference on Advanced Learning Technologies, 631-633.

Nawi, A. \& Hamzah, M. I.(2013). Tahap penerimaan penggunaan telefon bimbit sebagai M-Pembelajaran dalam Pendidikan Islam. Journal of Islamic and Arabic Education, 5(1), 1-10.

Ozdamli, F. \& Cavus, N. (2011).Basic Elements and Characteristics of Mobile Learning. Procedia-Social and Behavioral Sciences, 28, 937-942.

Russell, C. \& Ciesliek, N. (2012, July 17). Mobile phone access reaches three quarters of planet's population. Retrieved from http://www.worldbank.org/en/news/press-release/2012/07/17/mobile-phone-access-reachesthree-quarters-planets-population.

Song, H. S. Y., Murphy, A. \& Farley, H. (2013). Mobile devices for learning in Malaysia: Then and now. $30^{\text {th }}$ ascilite Conference 2013 Proceedings, 830-834.

Suki, N. M. \& Suki, N. M. (2010). Using Mobile Device for Learning: Students' Perspective. Proceedings of the 5th International Conference on E-Learning, 291-299

Traxler, J. (2007). Defining, Discussing and Evaluating Mobile Learning: the moving finger writes and having writ... International Review of Research in Open and Distance Learning, 8(2), 1-12. 


\section{Issues in Information Systems}

Volume 17, Issue IV, pp. 152-157, 2016

Wahab, A. D., Osman, A. \& Ismail, M. H. (2010). Engaging Children to Science Subject: A Heuristic Evaluation of Mobile Learning Prototype. 2010 Second International Conference on Computer Engineering and Applications, 513-516.

Wendeson, S., Ahmad, W. F. W., \& Haron, N. S. (2010). Development of Mobile Learning Tool Information Technology (ITSim). 2010 International Symposium, 1, 139-144.

Yi, C. C., Liao, W. P., Huang, C. F., \& Hwang, I. H. (2009). Acceptance of mobile learning: a respecification and validation of information system success. In Proceedings of World Academy of Science, Engineering and Technology, 41, 2070- 3740. 